\title{
Study of salinity effects on the inorganic phosphorus transformation in three different soil series of Ganges River Floodplain
}

\author{
Sonia Nasrin*, Tanmoy Kumar Biswas, Md. Sadiqul Amin and Monowara Khatun \\ Soil Science Discipline, Khulna University, Khulna-9208, Bangladesh
}

\begin{abstract}
The present study was carried out to investigate the effects of salinity level on different forms of inorganic phosphorus (P) transformation in three different soil series such as Amjhupi, Gopalpur and Bajoa located in Ganges River Floodplain. Two non-saline soils and one slightly saline soil with different textural classes were collected from these sites. The salinity treatments were 0,6 , 10 and $13 \mathrm{dSm}^{-1}$ with three replications. The treated soils were then incubated in laboratory at field capacity moisture condition. To determine the transformation of different forms of inorganic P, sampling was done for $0,14,21,42$ and 84 days. Different forms of inorganic P such as soluble and exchangeable phosphorus (SE-P), iron and aluminium bound phosphorus (Fe and $\mathrm{Al}-\mathrm{P}$ ), calcium bound phosphorus (Ca-P) and residual phosphorus (RE-P) were determined. For Amjhupi soil series, the sequence of different forms of inorganic $\mathrm{P}$ was $\mathrm{RE}-\mathrm{P}>\mathrm{Ca}-\mathrm{P}>\mathrm{Fe}$ and Al-P $>$ SE-P according to their amount. For Gopalpur and Bajoa soil series, the sequence was $\mathrm{Ca}-$ $\mathrm{P}>\mathrm{RE}-\mathrm{P}>\mathrm{Fe}$ and $\mathrm{Al}-\mathrm{P}>\mathrm{SE}-\mathrm{P}$ and $\mathrm{RE}-\mathrm{P}>\mathrm{Ca}-\mathrm{P}>\mathrm{Fe}$ and $\mathrm{Al}-\mathrm{P}>\mathrm{SE}-\mathrm{P}$, respectively. The sequence clearly indicates that the soluble and exchangeable $\mathrm{P}$ decreases with time due to salinity which reduces the uptake of $\mathrm{P}$ and ultimately reduces the yield. The changes were statistically significant $(p<0.0001)$ in case of all three soils.
\end{abstract}

Key words: Phosphorus transformation, Soil Series, Salinity, Yield.

\section{INTRODUCTION}

Soil salinity is distributed throughout the world especially in the arid and semi-arid regions, where agriculture performs under irrigation (Pessaraki \& Szaboles, 1999). The $\mathrm{P}$ deficiency frequently compounds the problem of saline of tropics (Landon, 1991). High salinity effects plant growth through the osmotic effects, toxicity of salt ions and the change in the physical and chemical properties of soil (Keren, 2000). It also suppresses the $\mathrm{P}$ uptake by plants roots and reduces the available $\mathrm{P}$ by sorption processes and low solubility of the Ca-P minerals (Grattan \& Grieve, 1998). Since, P is a critical element limiting plant growth, the adverse effects on plant growth in saline soil are multiplied. Due to the climate change, the sea level is rising day by day. For the increase of sea level, the intrusion of saline water in the river and from the estuary of the river to the upper portion the river is increasing in an alarming rate. Globally, it is becoming a threat for the human being to produce crops in the purpose of food due to the change in nutrients dynamics. On the other hand, in many irrigated areas of the arid and semi-arid regions, farmers are forced to use saline water to irrigate their crops due to an inadequate supply of fresh water. For the intrusion of saline water in the non-saline region, the cropping

\footnotetext{
*Corresponding author. E-mail: sonia_lopa@yahoo.com
} 
pattern is changing with time. The nutrients balance or nutrients dynamics in non-saline soil is different from saline soil. Plants may suffer from essential nutrients due to having antagonistic effect with the constituent of saline water. The interaction between salinity and nutrient uptake, including $\mathrm{P}$ by plants is a complex task. The interaction is highly dependent upon the plant species, plant developmental age, the composition and level of salinity and the concentration of $\mathrm{P}$ in the substrate (Grattan \& Grieve, 1998). Crop performance may be adversely affected by salinity-induced nutritional disorders. These disorders may result from the effect of salinity on nutrient availability, competitive uptake, transport or partitioning within the plant. For example, salinity reduces phosphate uptake and accumulation in crops grown in soils primarily by reducing phosphate availability but in solution cultures ion imbalances may primarily result from competitive interactions (Grattan \& Grieve, 1998). Navarro et al. (2001) reported that salinity decreased $\mathrm{P}$ uptake by melon seedlings (Cucumismelo L. cv. Galia) grown hydroponically at low $\mathrm{P}$ (high affinity uptake mechanism), although no specific competitive inhibition of $\mathrm{P}$ uptake by $\mathrm{Cl}$ was observed. Soil $\mathrm{P}$ exists in inorganic and organic forms. In most agricultural soils, $50-75 \%$ of $\mathrm{P}$ is inorganic form, although this fraction can vary from 1090\% (Sharpley \& Rekolainen, 1997). The Objectives of this present research work was to assess the transformation of different forms of inorganic $\mathrm{P}$ and to observe the effect of different levels of salinity on P transformation.

\section{METHODS AND MATERIALS}

A laboratory incubation experiment with three soil series of Ganges Floodplain were carried out to determine the influence of salt water on the transformation of native $\mathrm{P}$ at field capacity moisture condition. Two non-saline soils and one slightly saline soil with different textural classes were collected from Ganges River Floodplain. All the soils were collected at a depth of $0-15 \mathrm{~cm}$ on the basis of composite sampling. The collected soil samples were air dried ground and sieved through a $2 \mathrm{~mm}$ sieve. The samples were then preserved for analysis. The salinity treatments were $0 \mathrm{dSm}^{-1}\left(\mathrm{~T}_{1}\right), 6 \mathrm{dSm}^{-1}\left(\mathrm{~T}_{2}\right), 10 \mathrm{dSm}^{-1}$ $\left(\mathrm{T}_{3}\right)$ and $13 \mathrm{dSm}^{-1}\left(\mathrm{~T}_{4}\right)$ with three replications. Two hundred gram soil was incubated in $500 \mathrm{ml}$ capacity plastic container after application the treatments. The pots were covered with parafilms to prevent the loss of water through evaporation. The oven dry weight of the soil was determined gravimetrically. To determine the transformation of different forms of inorganic P, sampling was done for $0,14,28,42$ and 84 days from the incubated soils. The $\mathrm{P}$ fractions were extracted stepwise by wet chemical sequential extraction scheme by suing the modified version of the Hedley et al. (1982) procedure as the modified procedure is outlined by Alverez-Rogel et al. (2007). Different forms of inorganic P such as SE-P, Fe and AL-P, Ca-P and RE-P were determined. One gram of each soil sample was taken into centrifuge tube and different fractions were extracted by the sequential fractionation procedure. SE-P were extracted from each soil samples with $40 \mathrm{ml} 2 \mathrm{M} \mathrm{KCl}$ for 2 hours at room temperature with continuous agitation, $\mathrm{Fe}$ and Al-P were extracted from the residue of the first fraction of each soil samples with $40 \mathrm{ml} 0.1 \mathrm{M}$ $\mathrm{NaOH}$ for 17 hours with continuous agitation, Calcium bound $\mathrm{P}$ were extracted from the residue of second fraction of each soil samples with $40 \mathrm{ml} 0.5 \mathrm{M} \mathrm{HCl}$ for 24 hours with continuous agitation and RE-P were extracted from the last fraction of each soil samples 
from digestion with 5:2 mixtures of concentrated $\mathrm{HNO}_{3}$ and $\mathrm{HClO}_{4}$. The statistical analyses were done by using the statistical software SAS.

Table 1. General information about soil sampling sites

\begin{tabular}{|c|c|c|c|c|c|c|}
\hline $\begin{array}{c}\text { Sample } \\
\text { no. }\end{array}$ & GPS & $\begin{array}{c}\text { Soil } \\
\text { series }\end{array}$ & Physiography & Location & Land use & $\begin{array}{l}\text { Land } \\
\text { type }\end{array}$ \\
\hline 1 & $\begin{array}{c}23^{0} 28.234^{\prime} \\
\mathrm{N} \\
88^{0} 57.022^{\prime} \\
\mathrm{E}\end{array}$ & Amjhupi & $\begin{array}{c}\text { Ganges } \\
\text { Meander } \\
\text { Floodplain }\end{array}$ & $\begin{array}{l}\text { Vill: Suadi } \\
\text { Union: Dora } \\
\text { Upozilla: } \\
\text { Kotchandpur }\end{array}$ & $\begin{array}{l}\text { Rice-Zeya } \\
\text { mays-Mung }\end{array}$ & $\begin{array}{l}\text { Medium } \\
\text { Highland }\end{array}$ \\
\hline 2 & $\begin{array}{c}23^{0} 28.618^{\prime} \\
\mathrm{N} \\
88^{0} 56.543^{\prime} \\
\mathrm{E}\end{array}$ & Gopalpur & $\begin{array}{c}\text { Ganges } \\
\text { Meander } \\
\text { Floodplain }\end{array}$ & $\begin{array}{l}\text { Vill: Paka } \\
\text { Union: } \\
\text { Andulbaria } \\
\text { Upozilla: } \\
\text { Jebonnagor }\end{array}$ & $\begin{array}{l}\text { Rice-Zeya } \\
\text { mays-Mung }\end{array}$ & $\begin{array}{l}\text { Medium } \\
\text { Highland }\end{array}$ \\
\hline 3 & $\begin{array}{c}22^{0} 43.065^{\prime} \\
\mathrm{N} \\
89^{0} 01.797^{\prime} \\
\mathrm{E}\end{array}$ & Bajoa & $\begin{array}{c}\text { Ganges Tidal } \\
\text { Floodplain }\end{array}$ & $\begin{array}{l}\text { Vill: Khanpur } \\
\text { Union:Khanpur } \\
\mathrm{n} \\
\text { Upozilla: } \\
\text { Satkhirasadar }\end{array}$ & $\begin{array}{l}\text { Wheat/Veg } \\
\text { etables- } \\
\text { Rice- } \\
\text { Fallow }\end{array}$ & $\begin{array}{l}\text { Medium } \\
\text { Low } \\
\text { Land }\end{array}$ \\
\hline
\end{tabular}

\section{RESULTS AND DISCUSSION}

Soluble and Exchangeable Phosphorus (SE-P): SE-P contents of the soils varied with time after the application of different levels of salinity treatments. In Amjhupi soil series, the SE-P was increased slightly up-to 42 days with all treatments and then it was decreased sharply at 84 days except the treatment $\mathrm{T}_{4}$ (Fig. 1). For treatment $\mathrm{T}_{3}$ the SE-P was decreased slightly from 14 days to 42 days and for treatment $\mathrm{T}_{4}$ the SE-P was increased sharply from 14 days to 28 days and then it was decreased sharply. The pattern of changing of SE-P with $\mathrm{T}_{4}$ treatment was different from other treatments from 14 days to 42 days (Fig. 1). The change of SE-P of Amjhupi soil series with treatments and time was statistically significant $(p<0.0001)$. In Gopalpur soil series, the SE-P was decreased sharply up-to 28 days and then it was increased slightly from 28 days to 42 days and finally decreased at 84 days for all treatments (Fig. 2). The highest value was obtained at 0 days since the Gopalpur soil series was calcareous in nature, the change of SE-P due to the fixation of $\mathrm{P}$ with calcium and other elements and the change was statistically significant $(p<0.0001)$. For Bajoa soil series, the SE-P was increased up-to 14 days for all treatments and the highest value was obtained at 14 days for the treatment $\mathrm{T}_{1}$ and it was decreased at 28 days for all treatments (Fig. 3). At 42 days, the SE-P was increased for all treatments compared to 28 days and finally it was decreased at 84 days (Fig. 3). The increased and decreased of SE-P was due to the increase of soil $\mathrm{pH}$ and the fixation of $\mathrm{P}$ with phosphate fixing elements, respectively (Amin \& Hoque, 2005). The change of SE-P for Bajoa soil series with treatment and time was statistically significant $(p<0.0001)$. 


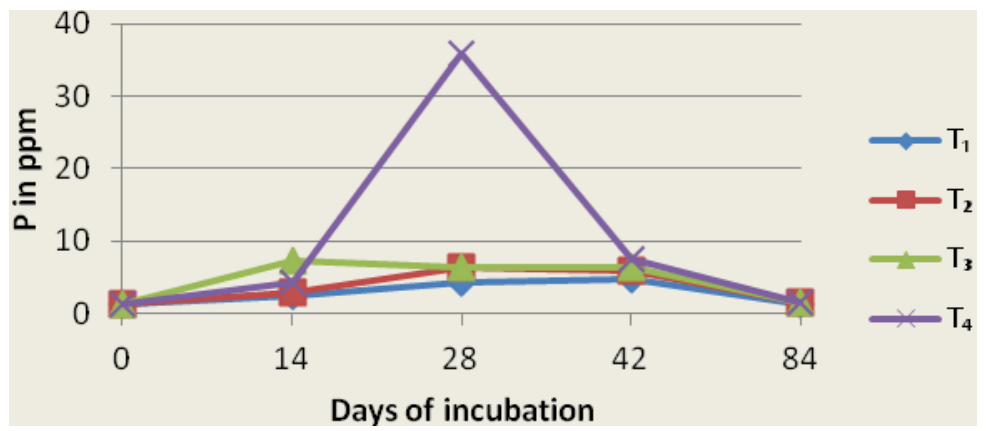

Fig. 1. Change in SE-P with time (Amjhupi Soil Series)

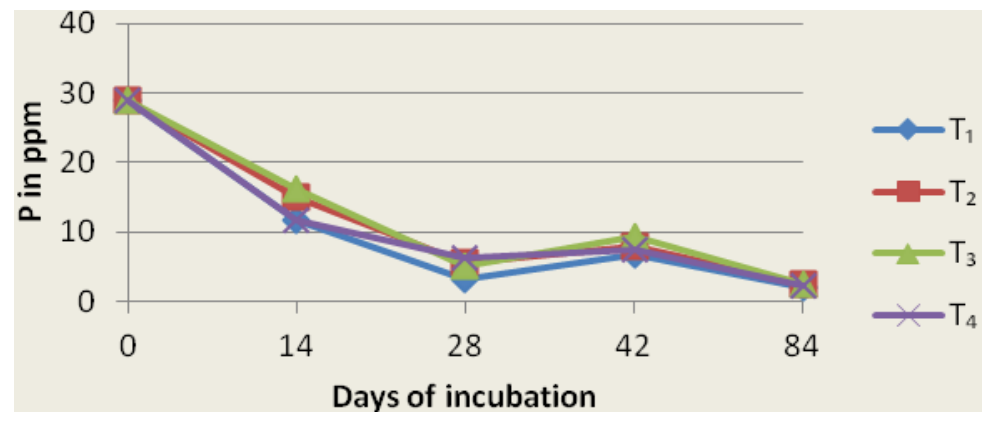

Fig. 2. Change in SE-P with time (Gopalpur Soil Series)

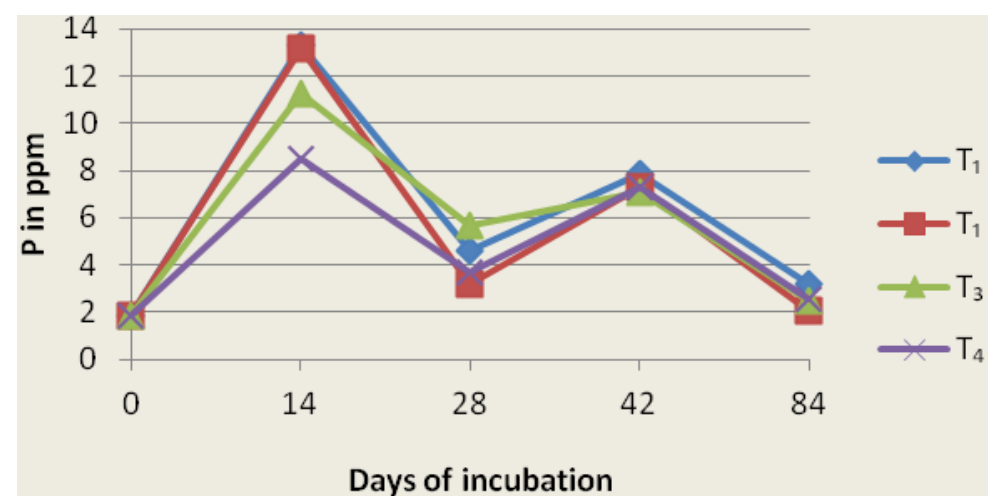

Fig. 3. Change in SE-P with time (Bajoa Soil Series)

Iron and Aluminium bound phosphorus (Fe and Al-P): In Amjhupi soil series, the Fe and Al-P were decreased from 0 days to 14 days for all treatments and then it was increased from 14 days to 42 days for all treatments (Fig. 4). The highest value was obtained for treatment $\mathrm{T}_{4}$ at 42 days. Finally, the amount Fe and Al-P were decreased at 84 days for all treatments (Fig. 4). The increased or decreased Fe and Al-P was due to the 
low $\mathrm{pH}$ or acidic nature of soil and the high $\mathrm{pH}$ or alkaline nature of soil with the time of incubation, respectively. The change of $\mathrm{Fe}$ and Al-P of Amjhupi soil series with treatments and time was statistically significant $(p<0.0001)$. For Gopalpur soil series, the Fe and Al-P increased slightly from 0 days to 14 days for all treatments and decreased at 28 days (Fig. 5). The highest value was obtained at 14 days for the treatments $T_{1}$. At 42 days, the Fe and Al-P were increased slightly but the value was relatively lower than 0 and 14 days. There was no change for the treatment $T_{2}$ from 42 days to 84 days and for others treatments; the values were decreased at 84 days (Fig. 5). The decreased Fe and Al$\mathrm{P}$ was due to the high $\mathrm{pH}$ or alkaline nature of soil. The change of $\mathrm{Fe}$ and Al-P of Gopalpur soil series with treatments and time was statistically significant $(p<0.0001)$. The Fe and Al-P were increased sharply from 0 days to 14 days for all treatments for Bajoa soil series (Fig.6). The highest value was obtained for treatment $\mathrm{T}_{1}$ at 14 days. At 28 days, the values were decreased from 14 days to 28 days and then it was slightly increased at 42 days and finally decreased at 84 days for all treatments. The initial increased of $\mathrm{Fe}$ and $\mathrm{Al}-\mathrm{P}$ was due to the acidic condition of soil and decreased of $\mathrm{Fe}$ and Al-P was due to the increase of $\mathrm{pH}$ (Rabbi et al, 2005). The change of Fe and Al-P with treatments and time was statistically significant $(p<0.0001)$.

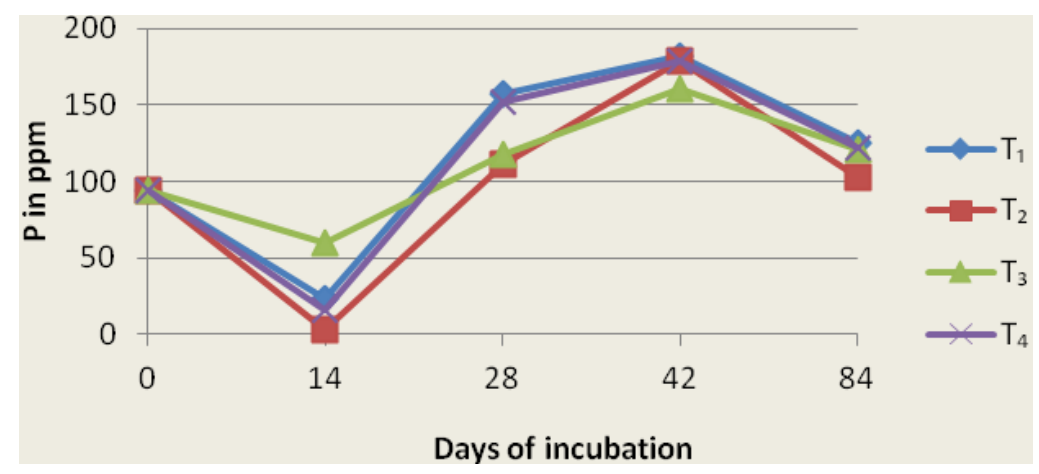

Fig. 4. Change in Fe and Al-P with time (Amjhupi Soil Series)

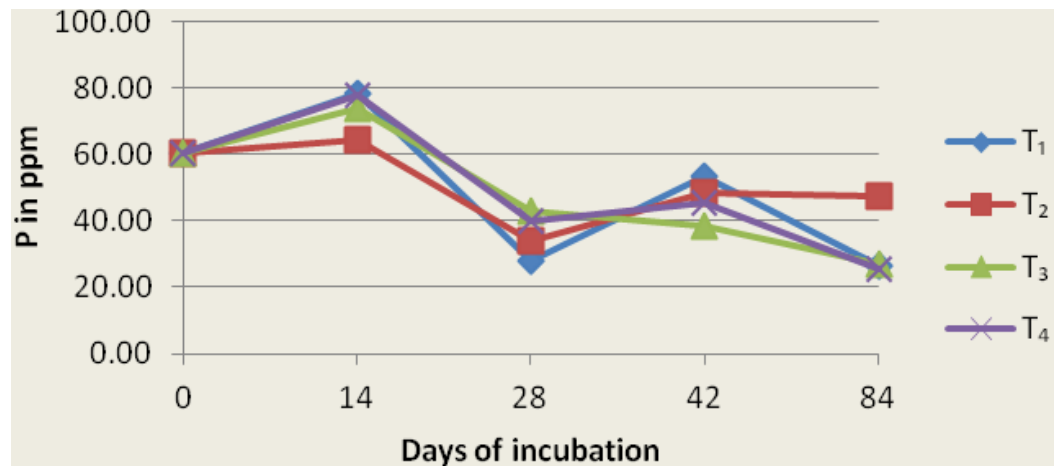

Fig. 5. Change in Fe and Al-P with time (Gopalpur Soil Series) 


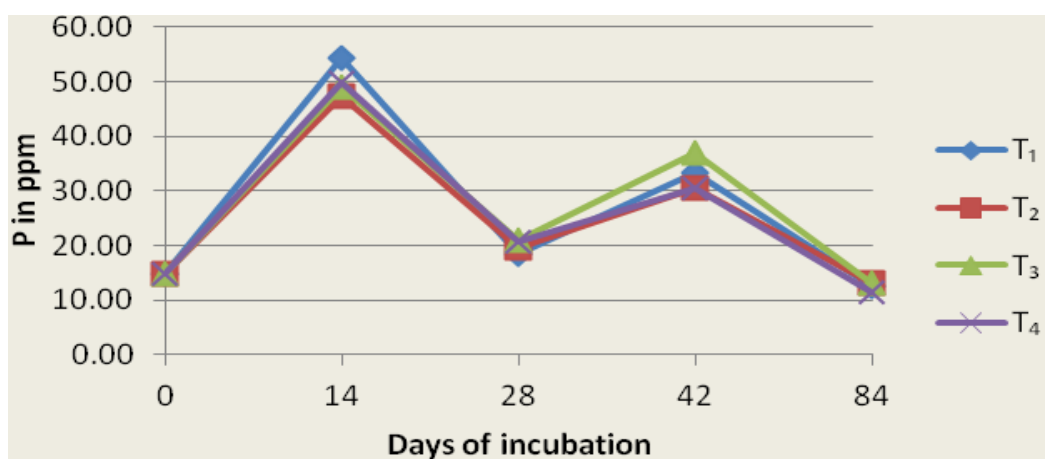

Fig. 6. Change in Fe and Al-P with time (Bajoa Soil Series)

Calcium bound Phosphorus (Ca-P): The Ca-P was increased from 0 days to 14 days for all treatments for Amjhupi soil series and then started to decrease from 14 days to 42 days for all treatments (Fig. 7). At 84 days, the content of Ca-P was increased for all treatments sharply except the treatment $\mathrm{T}_{2}$. For the treatment $\mathrm{T}_{2}$, the value also continued to decrease till 84 days from 14 days. The highest value of Ca-P was obtained at 84 days for the treatment $\mathrm{T}_{1}$. The initial increased of Ca-P was due to increase in soil $\mathrm{pH}$ (Rabbi et al, 2005 ) because the $\mathrm{pH}$ of the soil goes to neutral to slightly alkaline from 0 days to 15 days. The change of Ca-P with treatments and time was statistically significant $(p<0.0001)$. The Ca-P was increased from 0 days to 14 days for all treatments for Gopalpur soil series and then started to decrease from 14 days to 84 days for all treatments except the treatments $\mathrm{T}_{3}$ (Fig. 8). For treatment $\mathrm{T}_{3}$, Ca-P was increased from 0 days to 28 days and then started to decrease from 28 days to 84 days. The highest value was obtained at 14 days for the treatments $\mathrm{T}_{1}$. The change of Ca-P with treatments and time was statistically significant $(p<0.0001)$. The pattern of changing of Ca-P of Bajoa soil series was almost same as Gopalpur soil series. The Ca-P was increased from 0 days to 14 days for all treatments for Bajoa soil series (Fig. 9). For the treatments $T_{3}$ and $T_{4}$, $\mathrm{Ca}-\mathrm{P}$ was increased from 0 days to 28 days. The highest value was obtained at 28 days for the treatment $\mathrm{T}_{4}$. For the treatment $\mathrm{T}_{1}$ and $\mathrm{T}_{2}$, Ca-P started to decrease from 14 days and for the treatment $\mathrm{T}_{3}$ and $\mathrm{T}_{4}$, it started from 28 days to 84 days. The change of Ca-P with treatments and time was statistically significant $(p<0.0001)$.

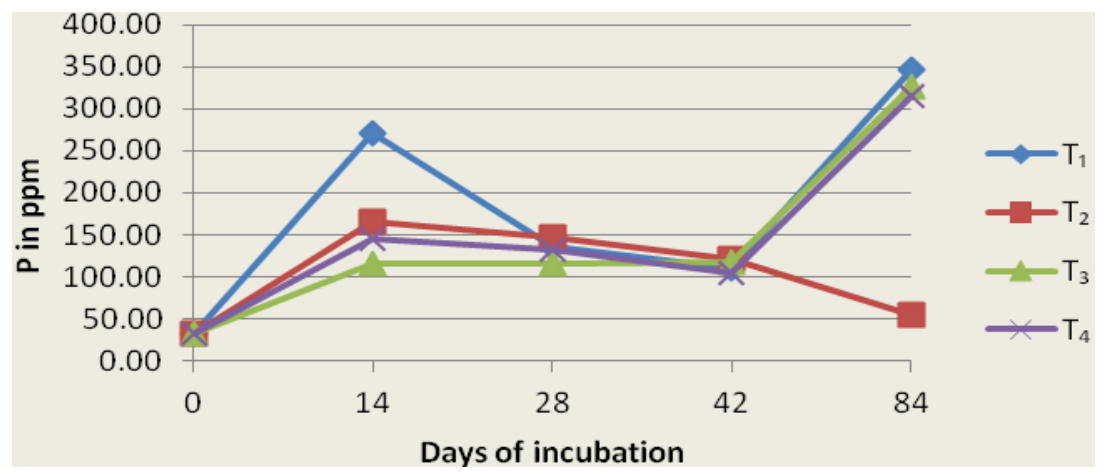

Fig. 7. Change in Ca-P with time (Amjhupi Soil Series) 


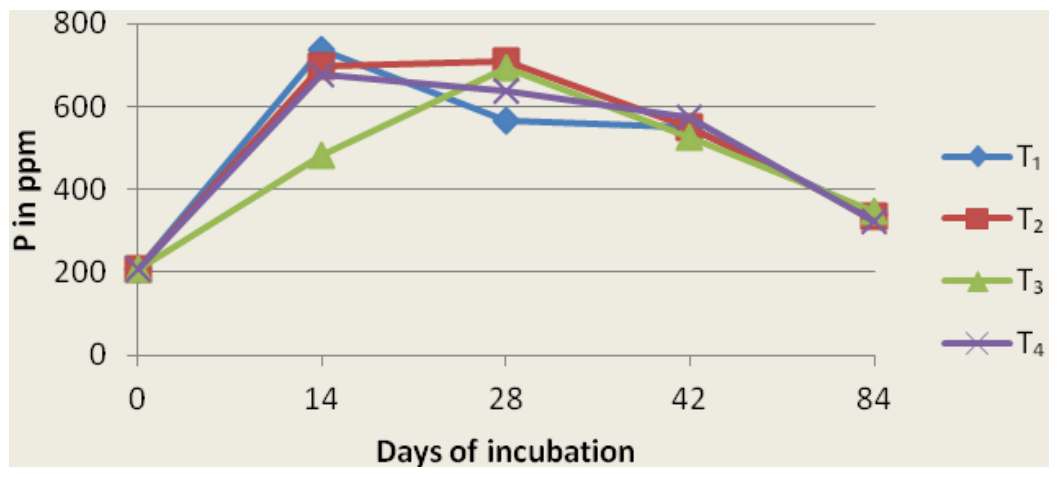

Fig. 8. Change in Ca-P with time (Gopalpur Soil Series)

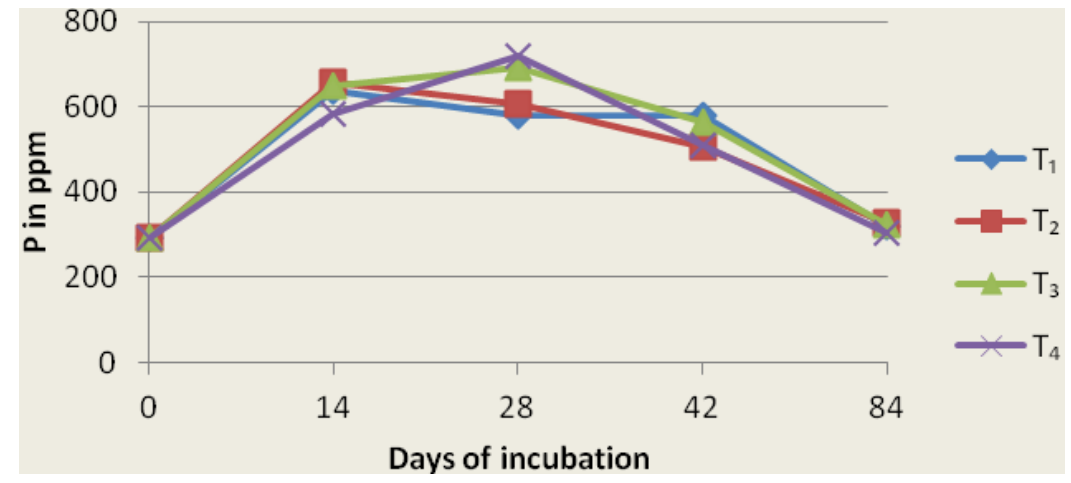

Fig. 9. Change in Ca-P with time (Bajoa Soil Series)

Residual Phosphorus (RE-P): The amount of RE-P contents of the soil depends on the other forms of inorganic phosphorus present in the soil. Increase or decrease of RE-P depends on the amount of increase or decrease of other forms of inorganic $\mathrm{P}$ in the soil. The highest values of RE-P for Amjhupi series were obtained at 0 days for all treatments (Fig. 10). The amount of RE-P was then started to decrease from 0 days to 84 days except the treatments $T_{2}$, because the value of RE-P of the treatment $T_{2}$ was increased at 84 days from 42 days. The change of RE-P with treatments and time was statistically significant $(p<0.0001)$. For Gopalpur soil series, the RE-P was decreased for all treatments from 0 days to 14 days but for the treatment $T_{3}$, it continued to decrease till 28 days (Fig. 11). The amount of RE-P was then started to increase gradually from 14 days to 84 days for all treatments. This increased of RE-P was due to the decreased of other forms of inorganic $P$ with time (Jain \& Sarkar, 1979). The change of RE-P with treatments and time was statistically significant $(p<0.0001)$. In Bajoa soil series, the RE-P was decreased for all treatments from 0 days to 14 days but for the treatment $T_{3}$ and $\mathrm{T}_{4}$, it continued to decrease till 28 days (Fig. 12). The amount of RE-P was then started to increase gradually from 14 
days to 84 days for all treatments. The change of RE-P with treatments and time was statistically significant $(p<0.0001)$.

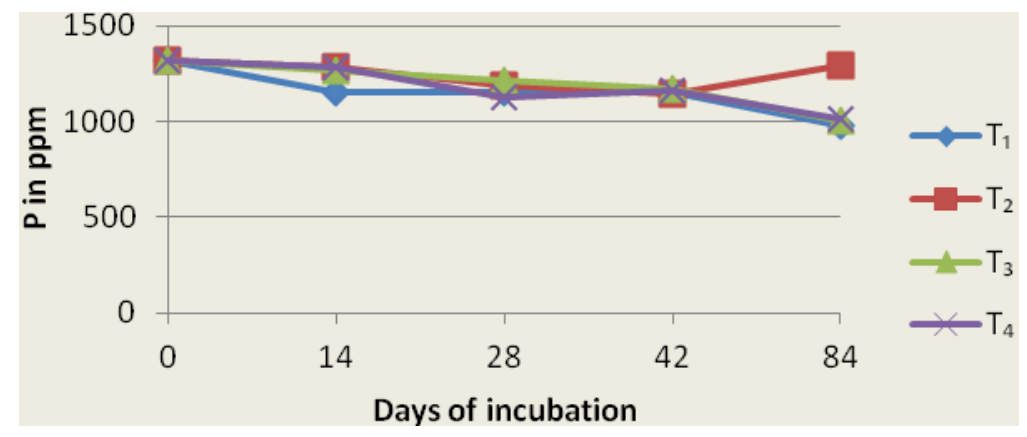

Fig. 10. Change in RE-P with time (Amjhupi Soil Series)

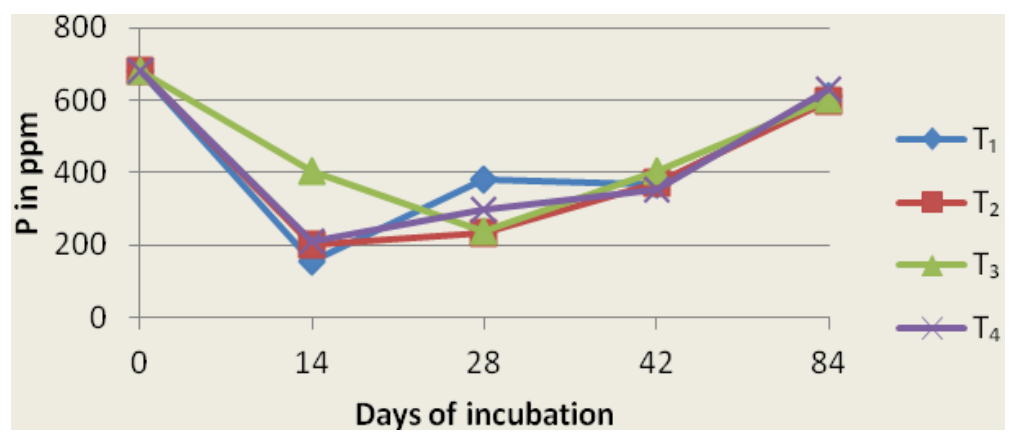

Fig. 11. Change in RE-P with time (Gopalpur Soil Series)

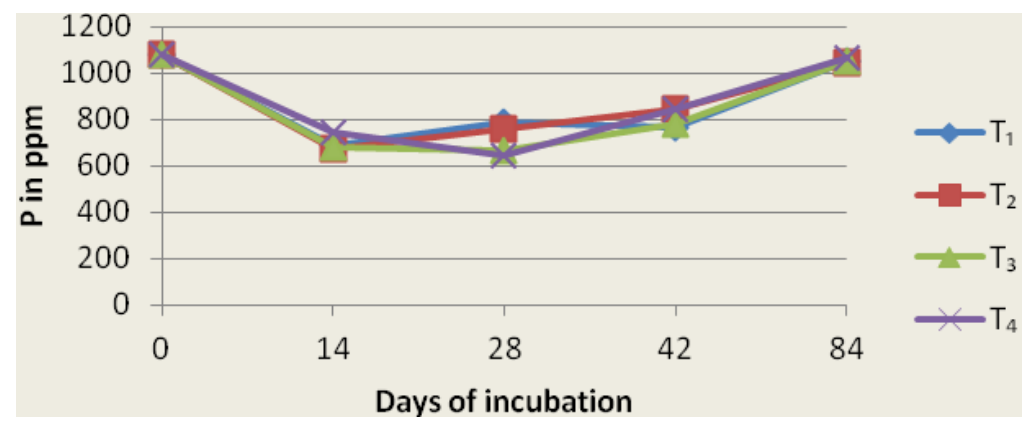

Fig. 12. Change in RE-P with time (Bajoa Soil Series)

The transformation of inorganic $\mathrm{P}$ occurred rapidly due to the influence of salinity. In the course of time the scenario of these transformations was shifted and showed different trend from that of the early stages of measurements. The amount of any one portion of the 
inorganic $\mathrm{P}$ transformation depends on the other forms of inorganic P. The increased or decreased of any portion of inorganic $\mathrm{P}$ was the results of the amount of other portions. Soil salinity reduces the availability of inorganic $\mathrm{P}$ to plants through the sorption process and making the low solubility of $\mathrm{P}$ fixing minerals. From the present experiment it was observed that soil salinity decreases the availability of P. As P is a double critical element, more research is required to study the effect of salinity on the transformation of soil $\mathrm{P}$.

\section{REFERENCES}

Alvarez-Rogel, J. Jimenez-Carceles, F.J. and Egea-Nicolas, C. 2007. Phosphorus retension in coastal salt marsh in Spain. Science of the Total Environment. 378: 71-74.

Amin, M.S. and Hoque, S. 2005. Influence of wheat growth on the transformation of inorganic phosphorus in Dhamrai soil. Bangladesh J. Soil Sci. 31(1-2): 21-27.

Grattan, S.R. and Grieve, C.M. 1998. Salinity-mineral nutrient relations in horticultural. Cropping Science of Horticulture. 78: 127-157.

Hedley, R.J., Stewart, J.W.B and Chauhan, B.S. 1982. Changes in inorganic soil phosphorus fractions induced by cultivation practices and by laboratory incubations. Soil Science Society of America. 46: 970-976.

Jain, J.M. and Sarkar, M.C. 1979. Transformation of inorganic phosphorus under field condition and its effect on P uptake and grain yield of wheat. Bull. Ind. Soc. Soil Sci. 12: 460-464

Keren, R. 2000. Hand book of soil science. CRC press. pp. 3-25.

Landon, J. R. 1991. Booker Tropical Soil Manual. John Wiley and Sons Inc, New York.

Navarro, J.M. Botella, M.A, Cerda, A. and Martinez, V. 2001. Phosphorus uptake and translocation in salt-stressed melon plants. Journal of Plant Physiology. 158: 375-381.

Pessarakli, M. and Szabolcs, I. 1999. Soil Salinity and Sodicity as Particular Plant/Crop Stress Factors. Handbook of Plant and Crop Stress, $2^{\text {nd }}$ edn. Marcel Dekker, Inc, New York. pp. 1-15.

Rabbi, S.M.F., Amin, M.S., Kibria, K.Q., Hossain, M.Z., Islam, M.S. and Khandakar, T. 2005. Short term effect of soil saline water application on some chemical properties of soils. Bangladesh Journal of Soil Science. 31(1-2): 45-53.

Sharply, A. 2000. Phosphorus availability. In Handbook of Soil Science. M.E. Boca, Raton. CRS. pp. 18-30. 